\title{
Investigation and calculation of a composite arch construction
}

\author{
Anastasiya Volovitskaya ${ }^{* 0000-0002-9575-5283]}$; Marat Salakhutdinov ${ }^{[0000-0002-9452-0271]}$ and Ivan \\ Kuznetsov $^{\text {[0000-0001-6838-0319] }}$
}

Kazan State University of Architecture and Building Engineering, Kazan, Russian

\begin{abstract}
One way to increase efficiency in the field of construction is to develop and improve new progressive design forms that reduce the consumption of materials, the complexity of manufacturing and erection, and the cost. These include a variety of combined systems, including arched ones.

Frameless arch systems have not been widely developed in our country due to the lack of adaptedness of the design concept to Russian climatic conditions, while frame arch systems have a high consumption of materials.

It is proposed to improve arch systems by increasing the spatial rigidity of the entire building made of rolled metal due to the combined action of the load-bearing frame and enclosing structures made of corrugated sheets. Thus, it becomes possible to use frameless arches on large spans. The use of such structures opens up wide opportunities for creating coverings that are characterized by lightweight and high technical and economic features.
\end{abstract}

\section{Introduction}

The practical application of frameless arched construction from cold-formed thin-sheeted steel profiles (Fig. 1) has great prospects. Low steel intensity and complexity of manufacturing and the speed of construction distinguishes these structures from similar frame structures [1-2]. The design and manufacturing technology of frameless structures is being improved by several foreign and Russian companies [3-7]. The most famous of them, including in Russia, are technology and equipment from Zeman International (Austria) and MIC Industries Inc (USA) [7- 9].

Initially, the technology of frameless arch construction was developed and patented in the United States. Still, it received limited use in Russia due to the lack of adaptedness to Russian climatic conditions [10].

The need to strengthen frameless structures (especially with spans over $18 \mathrm{~m}$ ) is due to the anisotropy of the corrugated system and insufficient stiffness of the shell in the direction of the forming cylindrical surface, which leads to frequent accidents (Fig. 2) [1123].

*Corresponding author: anastasik_15@mail.ru 


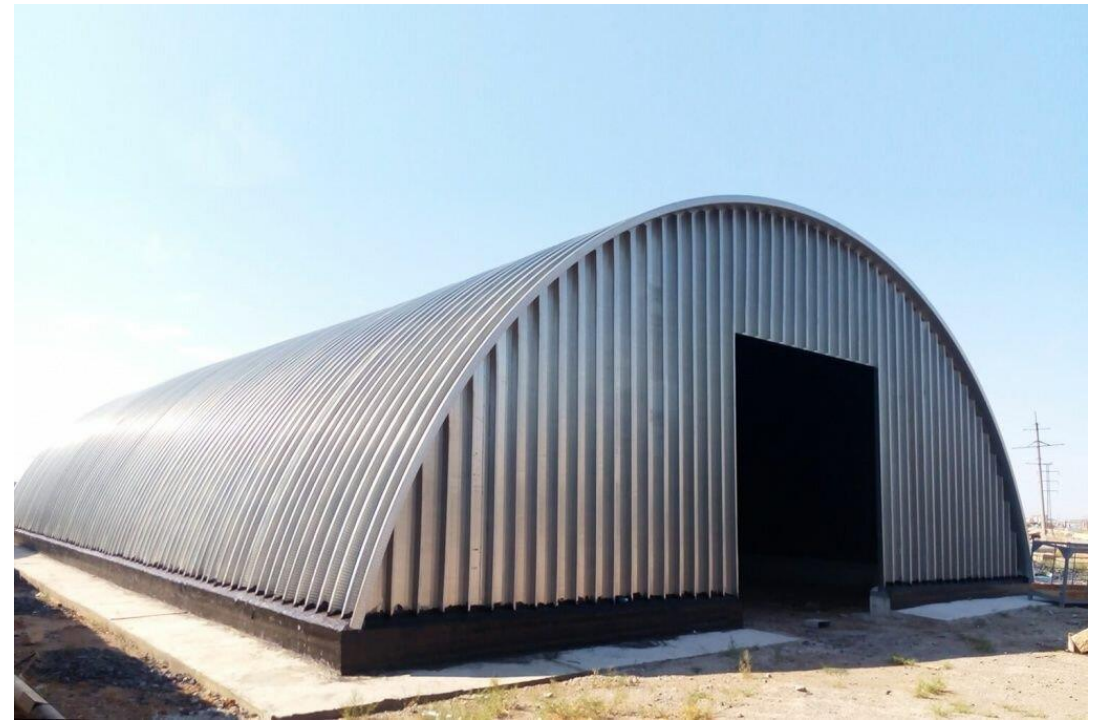

Fig. 1. General view of a frameless arched construction

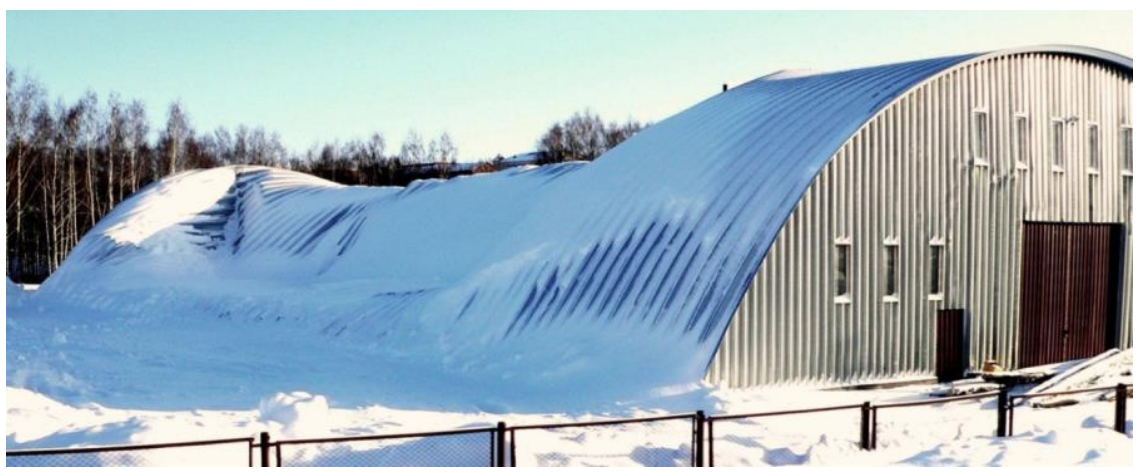

Fig. 2. The example of the collapse of a frameless arched building

In practice, in experiments and theoretical research, the main attention is focused on preventing the loss of stability of corrugated arched elements, for which, in particular, coldformed elements with double corrugation and modified corrugation elements are proposed; however, these options do not provide sufficient guarantees against collapse [22]. Thus, the task of developing new constructive solutions for arched buildings is becoming urgent, allowing to fully realize the potential of frameless technology for the construction of structures.

Frame arched construction is widely known, and they have proved successful in building a large span arch. A traditional framed arched construction includes metal arches supported directly on the foundation, coverings made in the form of the corrugated deck and metal purlins. An important issue in the building design with a system of flat load carrying arches is the creation of spatial rigidity by ensuring the stability of the arches from the plane, which is provided by a material-intensive system of bracing elements. Also, such systems require large material costs for the foundation [25-24].

This article proposes a design conception for an arched construction with a combined frame, including a load-carrying frame in the form of a laced or solid arch and enclosing structures made of ccorrugated deck. 
Simultaneously, the enclosing structures are included in combined action with the main supporting structures to ensure the spatial rigidity of the entire building. Thus, the technology for the production of frameless arches can be used for larger spans than they were originally calculated, and the reserves of the bearing capacity of the sheets will be used to absorb shear forces and reduce the consumption of steel for the beams.

\section{Methods}

The calculation will be performed by the method of computer simulation, which implements the finite element method.

As an example, we constructed a numerical model of a combined solution that includes a solid-section frame arch and a frameless arch connected by a system of purlins. The calculation will be performed by the finite element method in the program complex "SCAD". The collection of loads on the arched structure was carried out following the Russian Set of Rules SP 20.13330.2016 «Load and actions».

For the calculation, a double-hinged combined arch with a parabolic axis equation was adopted. The span of the arch is $12 \mathrm{~m}$, the lifting boom is $4 \mathrm{~m}$. A solid-section frame arch is included in the work of a frameless arch; the external load on the latter is transmitted through a system of purlins (the number of purlins varies). The purlins are modeled as bars hinged to the arches. Both arches are hinged and fixed in the support.

The arch is loaded with its own weight and skew-symmetric snow load with a calculated value of $280 \mathrm{~kg} / \mathrm{m}^{2}$ (Figure 3). To implement the transfer of the load from the snow, a hinge-rod chain is introduced into the circuit, which is formed from type 1 elements (flat truss rod), arch elements from type 2 elements (flat frame rod).

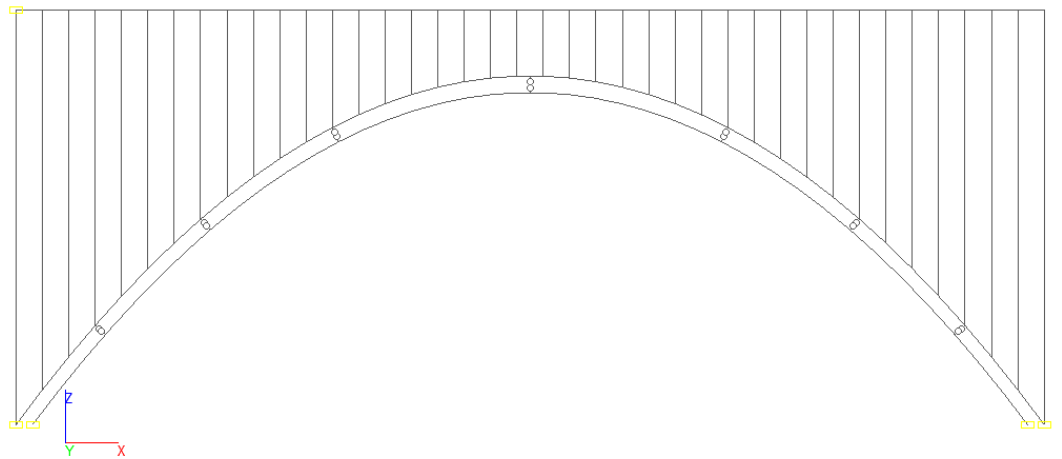

(a)

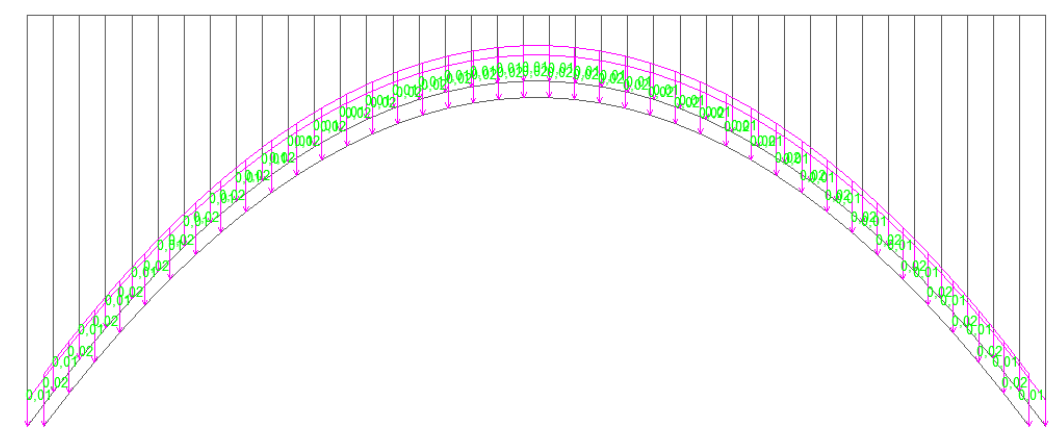

(b) setting the load from the self-weight of the structure 


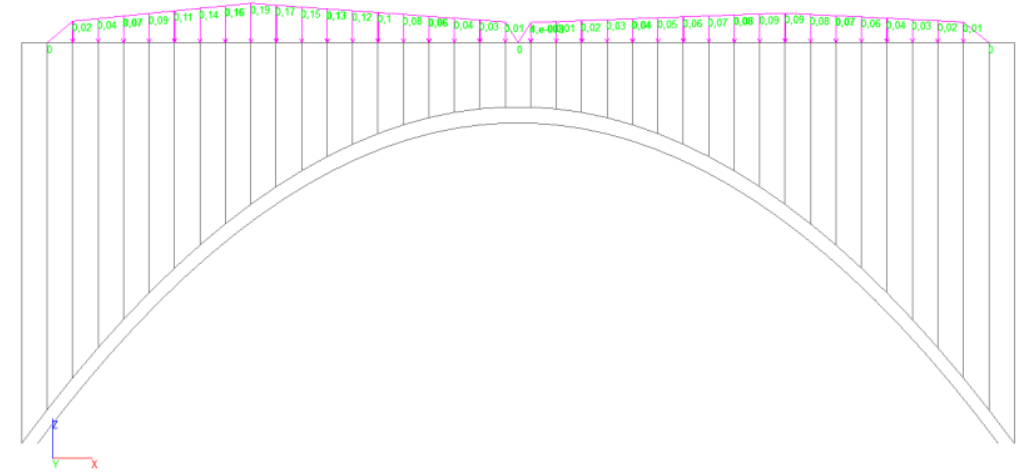

(c) setting the snow skew-symmetric load

Fig. 3. Design scheme of the arch (a) and the loading options adopted in the model (b) - (c)

To apply engineering techniques to the calculation of a frameless arched vault, its section is replaced by an equivalent one [25].

The results of the calculation are presented in table 1 . 
Table 1. Calculation results

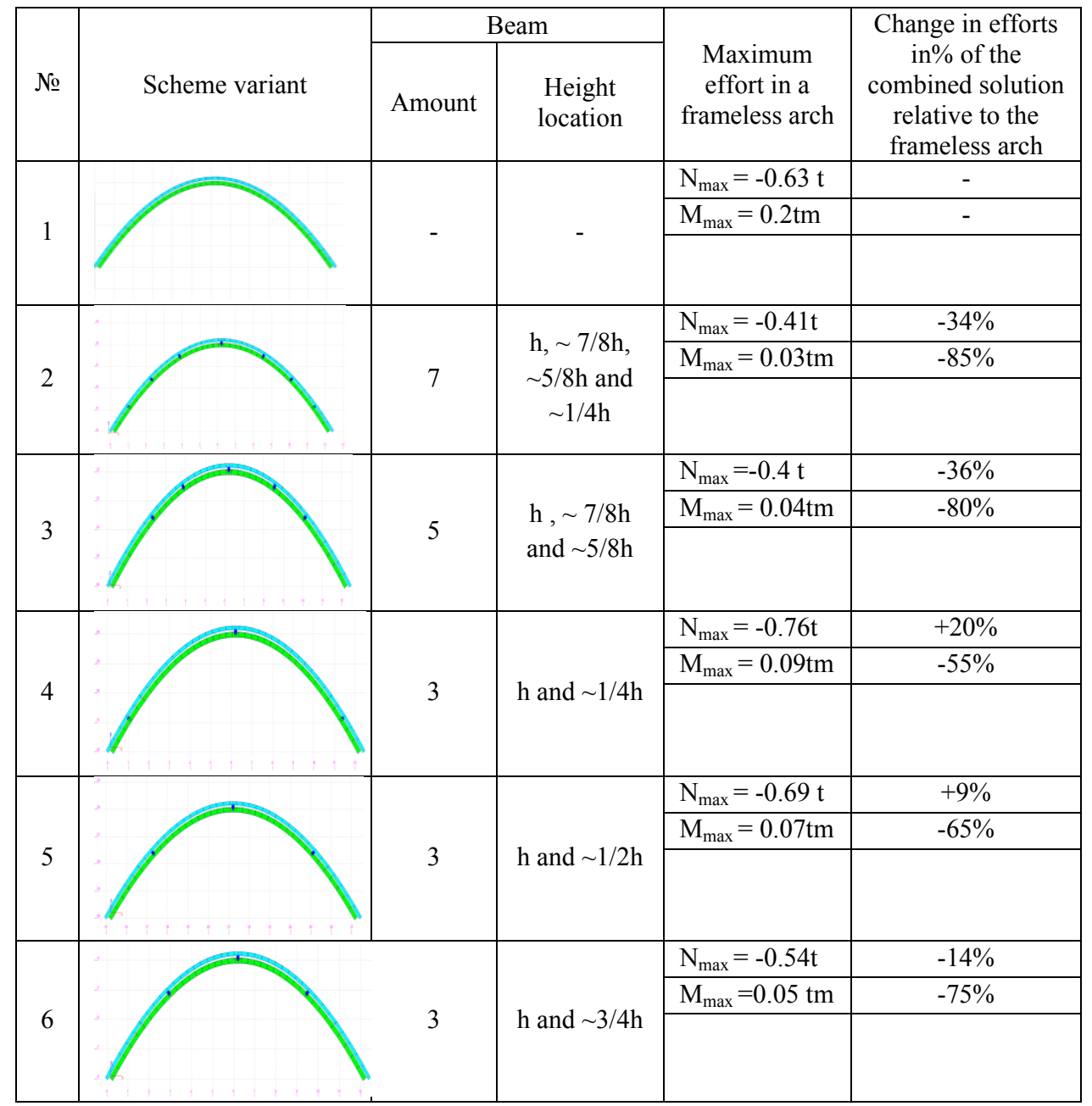

\section{Results and discussion}

Based on the results of the calculations, it was established that:

1) The greatest decrease in force $N_{\max }$ in a frameless arch with a combined solution according to scheme 3 (by $36 \%$ ).

2) An increase in the force $\mathrm{N}_{\max }$ in a frameless arch with a combined solution according to scheme 4 (increase by $20 \%$ ) and according to scheme 5 (by $9 \%$ ).

3) The effective longitudinal force in the frameless arch decreases with an increase in the number of girders that transfer the load to the frame arch.

4) Effectively reduces $\mathrm{N}_{\max }$ in a frameless arch the concentration of girders above $\sim \mathrm{h} / 2$.

5) With the chosen parabolic configuration of the double-hinged arch and the combined solution (joint work of the frameless and frame arch), there is a significant decrease in the bending moment in the frameless arch by $55 \ldots 85 \%$. Therefore, the main design value in the arch is not the bending moment but the longitudinal force. Consequently, with a combined solution of metal arches, the performance of a frameless arched structure will be determined, rather, not by the ability to resist bending but by stability. 
In research [26], on a numerical example of the implementation of a lightweight arched building with a frame made of thin-walled elements of the same type and a fence made of profiled steel decking is shown to be useful inclusion of cladding in joint work with bearing arches, while the decrease in maximum stresses in the design section of the arch compared to the autonomous operation of the building frame was $10.5 \%$, and deformations - $24 \%$. The results of these numerical experiments indicate the advisability of developing a combined solution to reduce efforts in a frameless arch.

\section{Conclusion}

Based on the results of the research carried out, the following conclusions can be drawn:

1. A numerical calculation of the combined solution of an arched structure, consisting of a frameless arch made of a cold-formed thin-walled profile and an arch frame, to which loads are transferred through a system of purlins, has been performed.

2. A possible redistribution of efforts has been established, namely, a decrease in the bending moment arising in a frameless arch by $80 \%$ and a longitudinal force by $36 \%$.

3. The combined solution will ensure the reliability of the frameless arched structure and reduce material consumption compared to frame solutions up to $20 \%$.

\section{References}

1. Pricker A.Y. Beskarkasnye skladchatye konstrukcii (K, Budivel'nik) p. 88, (1991)

2. Brudka Y.A. Stal'nye skladchatye konstrukcii v stroitel'stve ( K, Budivel'nik) p. 152, (1989)

3. Kondakova M.A. Oblast' primeneniya beskarkasnyh arochnyh konstrukcij Tekst: elektronnyj Geologiya i neftegazonosnost' zapadno-sibirskogo megabassejna (opyt, innovacii № 3, pp 44-48, (2016)

4. Karmanov I.V. Konstruktivnye resheniya beskarkasnyh arochnyh zdanij Sovremennoe sostoyanie i perspektivy razvitiya Stroitel'naya mekhanika i raschet sooruzhenij №5 pp 58-62, (2015)

5. Podzorov A.V. Imitacionnoe modelirovanie napryazhenno-deformirovannogo sostoyaniya tonkolistovogo profilirovannogo elementa $\mathrm{s}$ dvojnym gofrirovaniem Nauka i biznes: puti razvitiya № 5 (47) pp.103-105, (2015)

6. Zverev V.V. Tekhnologicheskie osnovy proizvodstva zdanij beskarkasnogo tipa na osnove tonkolistovogo prokata Materialy mezhdunarodnoj nauchno-prakticheskoj konferencii «Aktual'nye problemy sovremennogo stroitel'stva i puti ih effektivnogo resheniya» (Lipeck), (2013)

7. Makeev S.A., Rudak A.V. Matematicheskaya model' beskarkasnogo dvuslojnogo arochnogo svoda iz holodnognutyh tonkolistovyh stal'nyh profilej Stroitel'naya mekhanika i raschet sooruzhenij № 2, (2009)

8. Eremeev P.G., Kiselev D.B., Armenskij M.Y. K proektirovaniyu beskarkasnyh konstrukcij arochnykkh svodov iz holodnognutyh tonkolistovyh stal'nyh profilej Montazhnye i special'nye raboty v stroitel'stve №7, (2007)

9. Vedyakov I.I, Eremeev P.G Armenskij M.Y. Issledovaniya i proektirovanie beskarkasnyh arochnyh svodov iz holodnognutyh stal'nyh tonkolistovyh profilej Promyshlennoe i grazhdanskoe stroitel'stvo, №3, (2007)

10. Zhdanov D.A. Teoreticheskie issledovaniya pologih beskarkasnyh arochnyh pokrytij iz stal'nyh tonkostennyh holodnognutyh profilej Perspektivnye napravleniya innovacionnogo razvitiya stroitel'stva i podgotovki inzhenernyh kadrov: sb. nauch. 
statej HIH Mezhdunar. nauch.- metod. seminara, Brest, pp.68-75, (2014)

11. Ulasevich V.P. K ocenke vliyaniya geometricheskoj nelinejnosti na napryazhennodeformirovannoe sostoyanie pologih arok (Vestnik BrGTU № 1(67) Stroitel'stvo i arhitektura) pp 78-89, (2011)

12. Olejnik A.I. Ob effektivnosti vneshnego usileniya beskarkasnyh angarov (Izvestiya vuzov: Stroitel'stvo) №8, (2019)

13. Kiselev D.B. Rabota kombinirovannoj arochnoj sistemy s uchetom geometricheskoj nelinejnosti i posledovatel'nosti montazha: dis. ...kand. tekh. nauk: 05.23.01 / Kiselev Dmitrij Borisovich. (Moskva) p. 183, (2009)

14. Zhabinskij A.N. Modelirovanie arochnyh pokrytij iz tonkostennyh holodnognutyh profilej Tekhnicheskoe normirovanie, standartizaciya i sertifikaciya v stroitel'stve № 5 pp. $27-28,(20120$

15. Piekarczuk A. Stability and bearing capacity of arch-shaped corrugated shell elements: experimental and numerical study Bulletin of the polish academy of sciences technical sciences № 1, (2015).

16. Walentyński R. Local buckling and post-buckling investigation of cold-formed selfsupported Elements Computer Methods in Mechanics, (2013)

17. Walentyński R. Doubly corrugated cold-formed arch roof panels. Advanced identification of geometrical and material properties Architecture civil engineering environment №1, (2013)

18. Walentyński R, Cybulski R, Kozieł K Achilles' heel of the ABM120 double corrugated profiles. New Trends in Statics and Dynamics of Buildings (Slovakia University of Technology in Bratislava, Bratislava) pp.20-28, (2011)

19. Wu L L., Gao X.N., Shi Y.J., Wang Y.Q. Theoretical and Experimental Study on Interactive Local Buckling of Arch-Shaped Corrugated Steel Roof. Steel Structures, № 6 pp 45-54, (2006)

20. Xuanneng G, Haoming Z, Huihu Z. Research on Ultimate Bearing Capacity of Trapezium Corrugated Plate Assemblies Arch Steel Roof. IEEE pp. 2553-2556, (2011)

21. Liplenko M., Load-carrying capacity of frameless arched roofs structures with coldformed profiles EUROSTEEL, (2014)

22. Kuznecov I.L. Prichiny obrusheniya beskarkasnogo arochnogo sooruzheniya proletom 30 m Izvestiya (Kazan':KazGASU). № 4. pp 166-170, (2011)

23. Kuznecov I.L. Opyt stroitel'stva oblechennyh arochnyh zdanij i puti ih dal'nejshegosovershnstvovaniya Promyshlennoe i grazhdanskoe stroitel'stvo. (1987). № 1.

24. Kuznecov L.I. Raschet i konstruirovanie legkih arok: Uchebnoe posobie (Kazan':KGASA) p. 144, (1998)

25. Veselov Y.A., Karabutov M. Privedenie val'covannogo U- obraznogo profilya s reducirovannymi zhestkostnymi harakteristikami $\mathrm{k}$ gladkomu tavrovomu profilyu Raschet stroitel'nyh konstrukcij № 1, (2018)

26. Fahrutdinov A.E. Konstrukcii legkih arochnyh zdanij, realizuemyh po principu "otkrytoj" tipizacii: dis. ... kand. tekh. nauk: 05.23.01. (Kazan':KGASA) (2012) 